\title{
高波浪域向け消波型ケーソンの開発 THE DEVELOPMENT OF A WAVE ABSORBING CAISSON BREAKWATER FOR ROUGH SEAS
}

\author{
本田秀樹 $1 \cdot$ 塩崎禎郎 $1 \cdot$ 堀内 博 $2 \cdot$ 辻岡和男 2 \\ Hideki HONDA, Yoshio SHIOZAKI, Hiroshi HORIUCHI and Kazuo TSUJIOKA \\ 1 正会員 工修 N K K 基盤技術研究所 都市工学研究部（テ210-0855 神奈川県川崎市川崎区南渡田1-1） \\ 2正会員 工修 N K K 鉄構建設部 港湾技術グループ（テ230-8611 神奈川県横浜市鶴見区末広町2-1）
}

In open sea region with severe wave attacks, a breakwater covered with wave-dissipating blocks have been widely used. However, the application of this breakwater at greater depths implies the increase of construction costs because it requires a large quantity of wave-dissipating concrete blocks. Therefore, the authors developed a new type of breakwater. This breakwater consists of wave absorbing caisson and sloping top caisson. In this paper, through the sliding experiment of this new type breakwater using a $1 / 60$ model, we prove the stability and define the hydraulic characteristics of this breakwater.

Key Words : Wave absorbing caisson, sliding experiment, rough seas

\section{1.はじめに}

従来，外洋域における防波堤は，消波ブロックで 防波堤の前面を被覆する構造形式が採用されるケー スが多い。ところが，港湾の沖合展開に伴い，防波 堤の設置水深が増大すると, ブロック重量とその個 数が増加し, 建設コストの高騰が問題となることが ある。そのため, 耐波安定性, 消波性能に優れ，か つ経済的にも有利な防波堤の開発が課題となってい る。このような背景のもと，著者らは，高波浪域向 け消波型ケーソンの開発を進めてきた，その概略図 を困-1に示す。

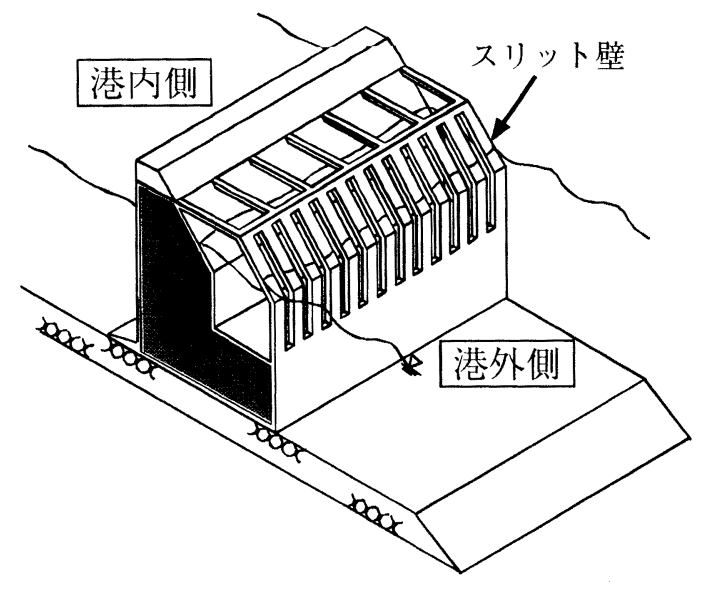

図-1 高波浪域向け消波型ケーソンの概略困
これは，反射率の低減に有利な直立消波ケーソン と, 耐波安定性に優れる上部斜面ケーソンの両方の 長所を組み合わせた構造である(以後, 上部斜面消波 ケーソンと記述する).したがって, 同じ波浪条件で 直立消波ケーソンと比較した場合, 堤体安定に必要 となる重量が少なくてすむため, 経済的に有利にな るものと考えられる。

そこで，実用化に向けて，上部斜面消波ケーソン の耐波安定性と消波, 越波特性を把握する目的で水 槽実験を実施した。本論文では，実験結果の概要を 示すとともに，設計で用いる波力算定式についても 検討を行っている。

\section{2. 実験概要}

\section{(1) 実験水路と模型断面}

\section{a) 実験水路}

実験は，吸収制御式の 2 次元造波水路(長さ $13.5 \mathrm{~m}$ $\times$ 高さ0.8m×幅0.9m) を用いて実施した. 水路図を図 -2 示す. 水路内には, 1/50勾配の水路床を設け, 造波板前面から8.15mの地点に模型を設置した。

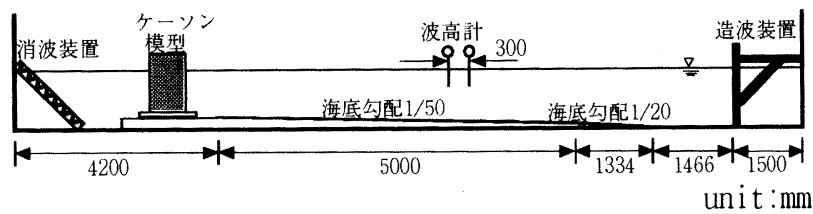

困-2 実験水路 


\section{b) 実験模型}

今回の実験では，上部斜面消波ケーソンの耐波安 定性を把握することが主な目的であるが, 実験の信 頼性向上とメカニズム解明のため, 直立消波ケーソ ンとの比較実験とした。実験対象は, 水深- $15 \mathrm{~m}$ に設 置される防波堤としている. 実験に用いた堤体模型 は，これらの断面を縮尺1/60でモデル化した。直立 消波ケーソンと上部斜面消波ケーソンの模型断面図 を図-3に示す。模型はアクリル製であり，底面はア ルミ版にサンドペーパーを貼付けることで捨石マウ ンドとの摩擦係数の調整を行った。また，スリット 部の開口率は $30 \%$ とた。

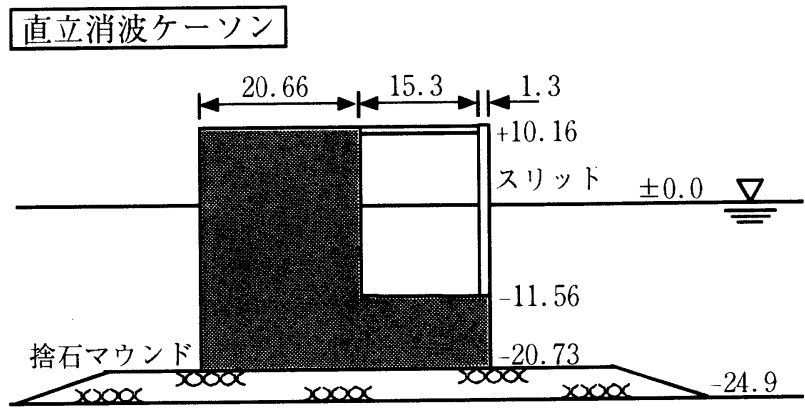

上部斜面消波ケーソン

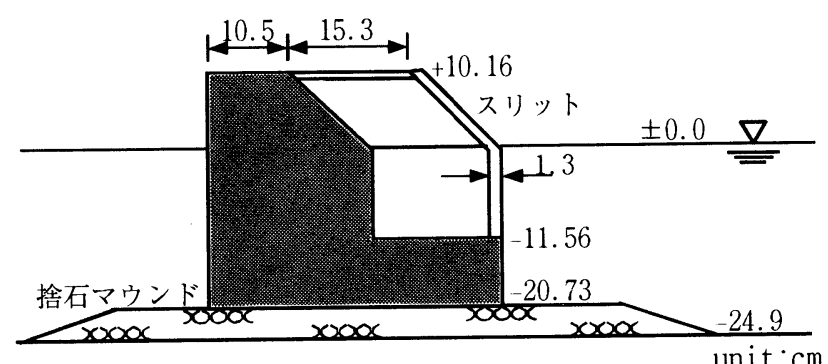

図-3 模型断面図

\section{(2) 実験条件}

今回は，基本的な堤体安定性と水理特性を把握す るため，規則波による実験とした。現地との想定縮 尺率は1/60で，フルード相似則に基づいて実験条件 を決定した。実験条件を表-1に示す．作用させた波 は, 同じ入力電圧值で造波しているため, 周期によ り若干波高が異なる。また, 実験条件とした波高は, 通過波高検定時における堤体設置位置での通過波高 である。

表-1 実験条件

\begin{tabular}{|c|c|c|c|}
\hline 縮尺率 & \multicolumn{3}{|c|}{$1 / 60$} \\
\hline 水深 & \multicolumn{3}{|c|}{$24.9 \mathrm{~cm}(15.0 \mathrm{~m})$} \\
\hline 周期T & $\begin{array}{c}1.29 \mathrm{~s} \\
(10.0 \mathrm{~s})\end{array}$ & 波高H & $\begin{array}{c}4.6 \mathrm{~cm}(2.8 \mathrm{~m}), 10.2 \mathrm{~cm}(6.1 \mathrm{~m}), \\
14.1 \mathrm{~cm}(8.5 \mathrm{~m}), 14.1 \mathrm{~cm}(8.5 \mathrm{~m})^{*}\end{array}$ \\
\hline 周期T & $\begin{array}{c}1.88 \mathrm{~s} \\
(14.5 \mathrm{~s})\end{array}$ & 波高H & $\begin{array}{c}5.1 \mathrm{~cm}(3.1 \mathrm{~m}), 12.0 \mathrm{~cm}(7.2 \mathrm{~m}), \\
17.5 \mathrm{~cm}(10.5 \mathrm{~m}), 15.9 \mathrm{~cm}(9.5 \mathrm{~m})^{*}\end{array}$ \\
\hline
\end{tabular}

*)捨石マウンド手前で砕波 （）は現地換算值

\section{（3）実験方法}

\section{a) 水平載荷実験}

滑動実験は, 波を作用させた時の堤体重量と, 変 位の関係が重要となるため, 実験前に堤体底面と捨 石マウンドとの摩擦係数を求めておく必要がある. この摩擦係数を求めるために, 水平載荷実験を実施 した. 水平載荷実験は, 堤体に加える水平力を徐々 に増加させ, 堤体が変位した時の水平力と堤体重量 の比から摩擦係数を求める方法である。 今回は, 堤 体底面をアルミ製としたことから，設計時に用いる 摩擦係数值 $\mu=0.6$ に合わせるため, 底面にサンドペ ーパーを貼付けた。実験は, 堤体の重量を変化させ て行い, 堤体重量と摩擦係数の関係を求めた. 堤体 重量は，堤体内に入れる錘を増減させることで調整 した. 実験で使用した捨石マウンドは砕石6号をふる い分け，粒径5～13mmの砕石を用いて作成した。これ

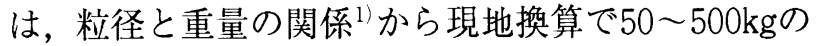
石材に相当する。なお, 実験の際には, 実現象に近 づけるため捨石マウンドを水没させた。

水平載荷実験から得られた摩擦係数を図-4に示す。 摩擦係数は，実験ケースごとにばらついているが, 今回は, 平均值 $\mu=0.59$ を実験結果の整理に用いるこ とにした。

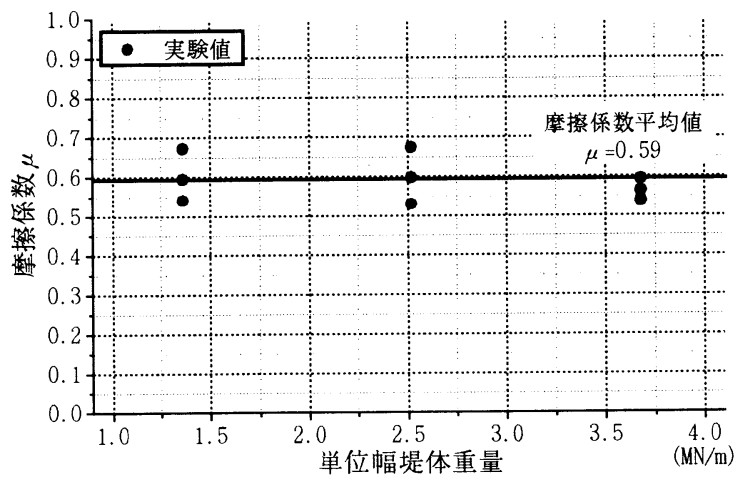

図-4 堤体重量と摩擦係数の関係

\section{b) 滑動実験}

滑動実験は，谷本ら ${ }^{2)}$ が行った実験方法を参考に した。滑動実験の概略図を図-5に示す。今回は，堤 体全体に作用する水平波力, 鉛直波力, 及び, 堤体 に作用する波圧を同時に計測するために模型を防波 堤法線方向に 3 分割し, それぞれ, 滑動量測定用, 波力測定用，波圧測定用とした。滑動量の測定に用 いた堤体模型を写真-1に示す。また，捨石マウンド は，水平載荷実験と同じ砕石を用いて滑動量測定用 の堤体部分のみ作成した。

実験では，最初に，作用させる波に対して，基本 となる堤体重量を定める。この堤体重量の算定には, 次の波力算定式を用いた。

\section{【波力算定式】 \\ [直立消波ケーソン]}

堤体に作用する波圧分布を代表的な6つの位相に分 け，それぞれの位相に対して合田式に直立消波ケー 
ソンの効果を取り入れるため，補正係数を掛け合わ せた高橋らの算定式 3 .

\section{[上部斜面消波ケーソン]}

直立消波ケーソンの算定式に，上部斜面ケーソンに 対して細山田ら ${ }^{4)}$ が提案している斜面部，直立部の 波力低減係数を掛け合わせた算定式.

これらの算定式を用いて, 滑動安全率S.F. $=1.0$ とな るときの堤体重量を求め，この重量となるように滑 動量測定用模型内に錘を入れ，水路内に設置した。 次に，波を作用させ，堤体背後の上下2箇所に設置し た防水型変位計で堤体の変位量を計測し，堤体下側 に設置した変位計の計測值を堤体の滑動量とした。 堤体下側の変位時系列波形において, 1波で $1 \mathrm{~mm}$ (現地 換算で $6 \mathrm{~cm})$ 以上の滑動が見られたときは，堤体が滑 動したものと判断して堤体重量を増加させ, 堤体が 安定していれば堤体重量を減少させて実験を繰返し 行い，堤体が滑動する直前の重量を滑動限界重量と した.1回の実験終了後，捨石の散乱が見られた場合 は捨石マウンドを元の状態に戻し，堤体を据付け直 してから次の害験を開始した。なお，水平波力，鉛 直波力の計測には3分力型のロードセル, 波圧の計測 は波圧計を使用し, サンプリング周波数 $500 \mathrm{~Hz}$ でデー 夕の収集を行った。

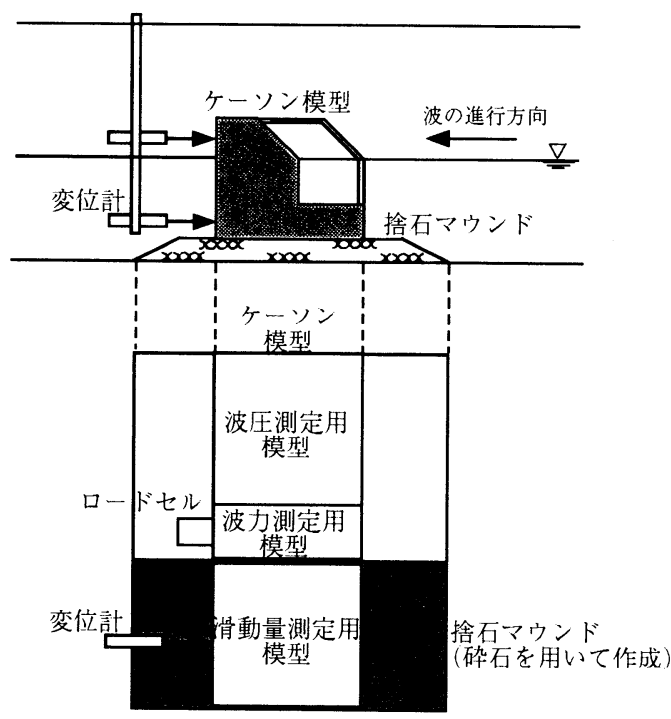

図-5 滑動実験概略図

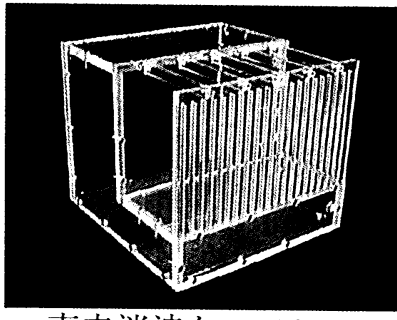

直立消波ケーソン

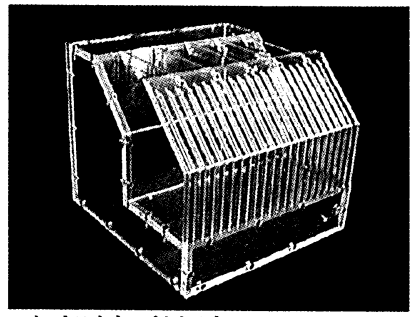

上部斜面消波ケーソン 写真-1＼cjkstart滑動実験用模型

\section{3. 実験結果}

\section{(1) 滑動実験}

\section{a) 滑動量と堤体重量の関係}

実験結果の一例として, 周期 $\mathrm{T}=14.5 \mathrm{~s}$, 波高 $\mathrm{H}=7.2 \mathrm{~m}$ と $\mathrm{T}=10.0 \mathrm{~s}, \mathrm{H}=6.1 \mathrm{~m}$ に対する単位幅堤体重量と滑動量 の関係を, それぞれ図-6, 図-7に示す。縦軸は, 1 波ごとの堤体の滑動量を1回の実験に対して10波分, 繰返し実験数 2 回についてプロットしており,横軸は それぞれの実験時での単位幅堤体重量である。また, 図中の黑印は, 10波分の滑動量の平均值で, 実線は その近似曲線である。図-6, 図-7からも明らかなよ うに, 堤体の滑動量は1波ごとに異なっており, 同じ 堤体重量に対しても滑動の有無や, 滑動量がばらつ くことがわかる。ここでは，10波の滑動量がすべて $1 \mathrm{~mm}$ (現地換算 $6 \mathrm{~cm}$ ）以内であれば滑動しないものと 判断し, 滑動しない堤体重量のうち最小の堤体重量 を滑動限界重量とした。 上部斜面消波ケーソンと直 立消波ケーソンの滑動限界重量を比較すると, 波高 の小さいケースでは両者の差はあまり見られなかっ たが, 波高の増大に伴って斜面の効果が大きくなり， その差は顕著になった。今回の実験ケース中, 最大 波高時 $(\mathrm{T}=14.5 \mathrm{~s}, \mathrm{H}=10.5 \mathrm{~m})$ における上部斜面消波ケ ーソンの滑動限界重量は，直立消波ケーソンの0.74 倍であった。このことから，上部斜面消波ケーソン は直立消波ケーソンよりも耐波安定性に優れている ものと判断できる.

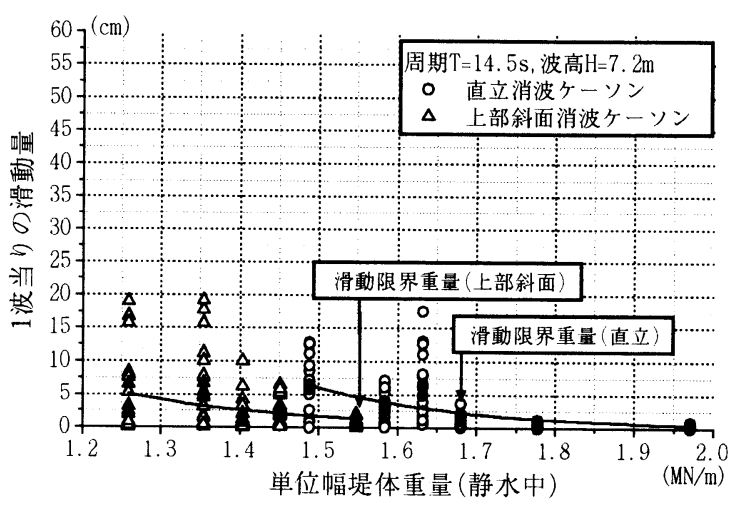

図-6 単位幅堤体重量と滑動量の関係 （周期 $\mathrm{T}=14.5 \mathrm{~s}$, 波高 $\mathrm{H}=7.2 \mathrm{~m}$ )

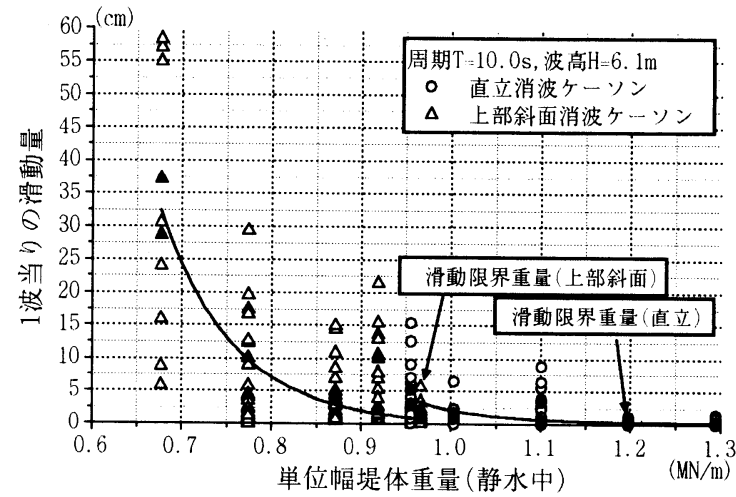

図-7 単位幅堤体重量と滑動量の関係

(周期 $\mathrm{T}=10.0 \mathrm{~s}$, 波高 $\mathrm{H}=6.1 \mathrm{~m}$ ) 


\section{b) 波力算定式の検討}

ここでは，滑動実験で仮定した波力算定式の妥当 性を検討する，直立消波ケーソンと上部斜面消波ケ ーソンについて，滑動実験で求めた滑動限界重量We と, 波力算定式から求めた滑動限界重量Wcの比を図 -8, 図-9に示す。ここで, Wcは滑動安全率S. F. $=1.0$ となるときの堤体重量である．図の縦軸はWeとWcの 比であり, We/Wc>1.0では今回用いた波力算定式が危

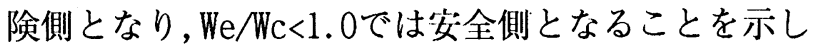
ている，今回の実験結果では，直立消波ケーソンと 上部斜面消波ケーソンのWe/Wcは, 0.8〜1.1の範囲に 分布している.また, We/Wcの平均值は, 雨者とも 1.0 を下回っており，仮定した波力算定式は妥当なもの と判断できる。

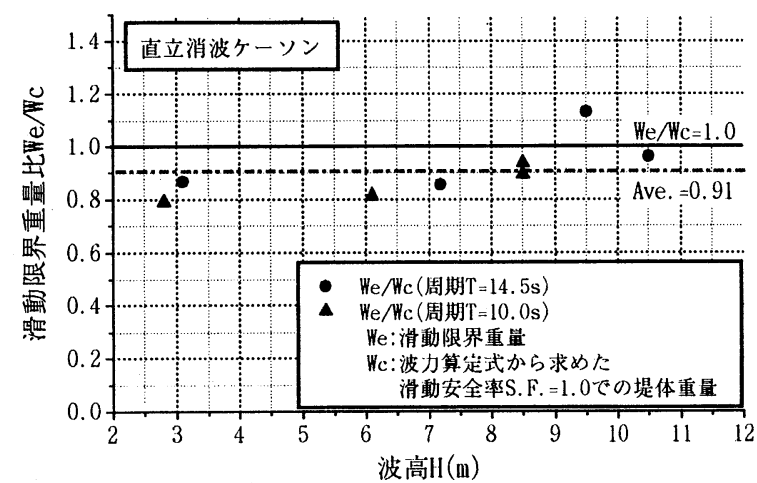

困-8 滑動限界重量の比較(直立消波ケーソン)

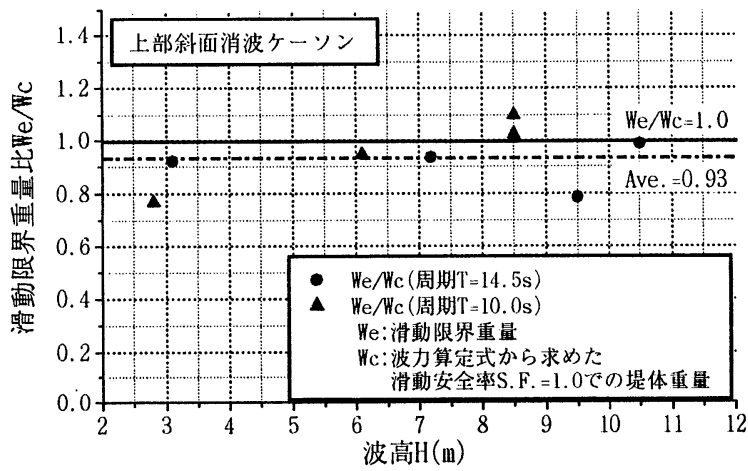

図-9 滑動限界重量の比較(上部斜面消波ケーソン)

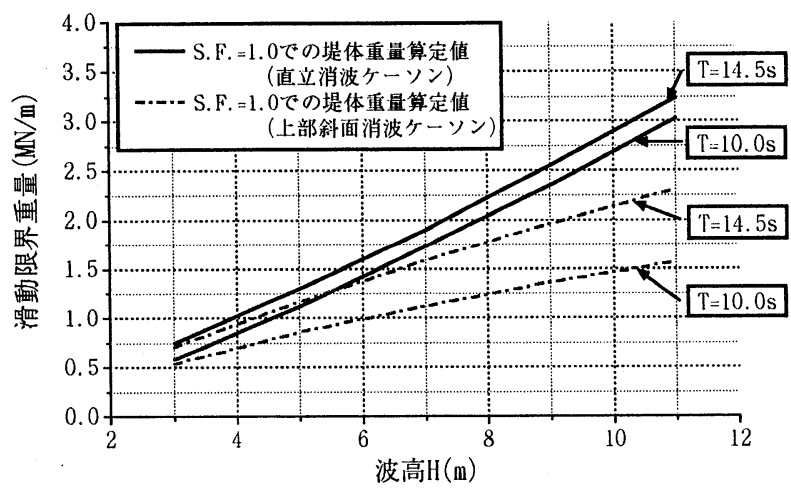

図-10 滑動限界重量の比較

（開口率 $30 \%$, 水深 $\mathrm{h}=15.0 \mathrm{~m}$, 周期 $\mathrm{T}=10.0 \mathrm{~s}, 14.5 \mathrm{~s}$ )
図-10は，この波力算定式に基づき，今回の断面媭状 に刘して波高を変化させたときの，直立消波ケーソ ンと上部斜面消波ケーソンの滑動限界重量を試算し た結果である。その結果，波高の比較的小さい範囲 においては，直立消波ケーソンと上部斜面消波ケー ソンの差はほとんど見られないが, 波高の増大とと もに，その差は顕著になる。このように，上部斜面 消波ケーソンは，高波浪域において非常に有利な構 造形式と考えられる。

\section{c) 滑動メカニズムの検討}

次に，滑動実験結果と計測した波力值をもとに， 滑動のメカニズムについて考察を行った。写真-2は, 堤体に波が作用している状況であり，この時点での 堤体に作用する力を模式的に示したのが図-11であ る．滑動合成波力Fcは堤体の滑動安定性の検討に用 いる值であり，次式で算定される。

\section{$\mathrm{Fc}=$ 水平波力 一摩擦係数 $\times($ 鉛直波力一揚圧力 $)$}

ここで，水平波力，鉛直波力は波力測定用模型に 取付けたロードセルの测定值を用い，揚圧力は堤体 前面下端で測定した压力計の值を代用した。 また， 滑動抵抗力 $\mu W^{\prime}$ は，水平載侍実験より求めた摩擦係 数 $\mu$ に静水中の堤体重量Wを乗じた值で, 堤体が作 用する波力に抵抗する力である。

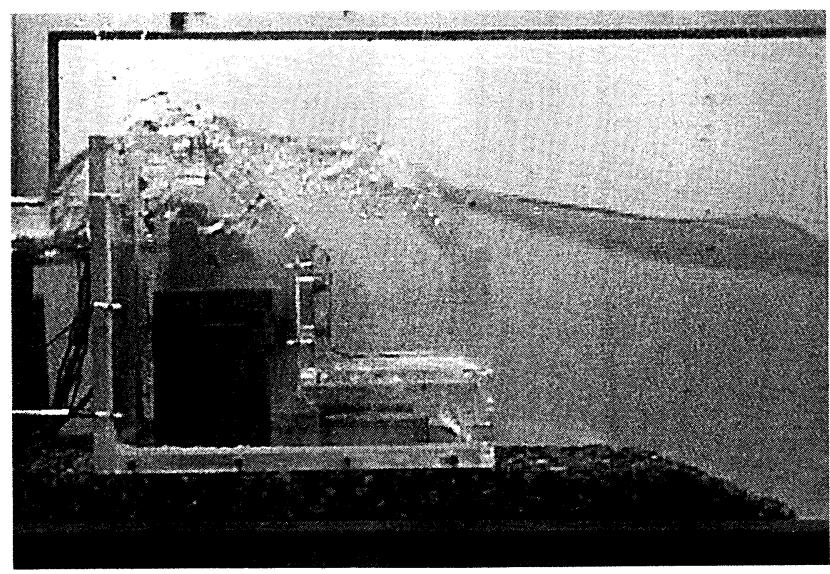

写真-2 波の作用状況

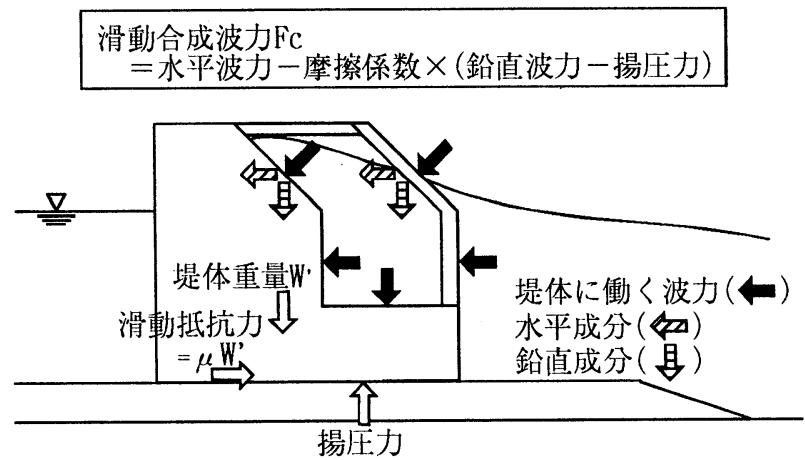

図-11 作用力の模式図 
堤体の滑動は, 物理的には $\mathrm{FC}=\mu \mathrm{W}$ 'を境界として, $\mathrm{FC}>\mu \mathrm{W}$ ’となった時に発生し, $\mathrm{FC}<\mu \mathrm{W}$ ’では発生しな い。このことを確認するために，上部斜面消波ケー ソンの滑動合成波力と堤体変位の時系列波形の一例 として, $\mathrm{FC}>\mu \mathrm{W}$ 'となる条件を図 $-12, \mathrm{FC}=\mu \mathrm{W}$ 'となる 条件を図一-13に示す。

図-12では，Fcが $\mu W$ を大きく上回るため，変位時 系列波形が階段状となり，堤体の滑動量が蓄積され ていく様子がわかる。図-13は，Fcと $\mu$ W'が一致する 条件で，滑動の有無が混在する臨界状態である，以 上の結果から，堤体の安定性は滑動合成波力F 動抵抗力 $\mu$ W'の関係から評価できることがわかる.

また，堤体変位の時系列波形に着目すると，堤体 の変位は，Fcが堤体に向かって作用する $\mathrm{Fc}>0$ となる 時刻から始まるＦCがピークをむかえた後も変位は 増加し, 変位のピークはFCのピークと位相差をもっ て生じる。この現象は，下迫ら ${ }^{5}$ が提案している混 成防波堤の滑動モデルと同様の現象であった，堤体 の変位がピークとなった後，堤体は沖方向に戻る。 これは, 捨石マウンドの弾性変形が元に戻る影響や， 波浪条件によっては，引き波時の波圠よる滑動現 象が生じている可能性も考えられる。

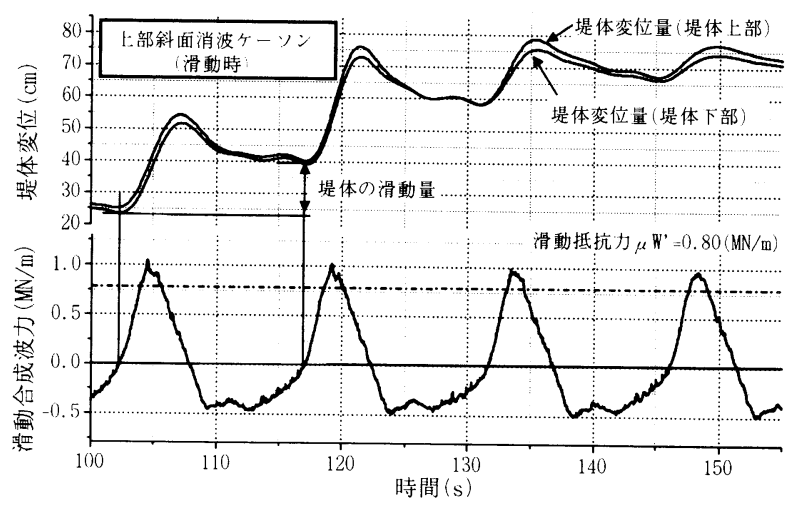

図-12 堤体変位量と滑動合成波力の時系列波形 $\left(\mathrm{T}=14.5 \mathrm{~s}, \mathrm{H}=7.2 \mathrm{~m}, \mathrm{~W}^{\prime}=1.354 \mathrm{MN} / \mathrm{m}\right)$

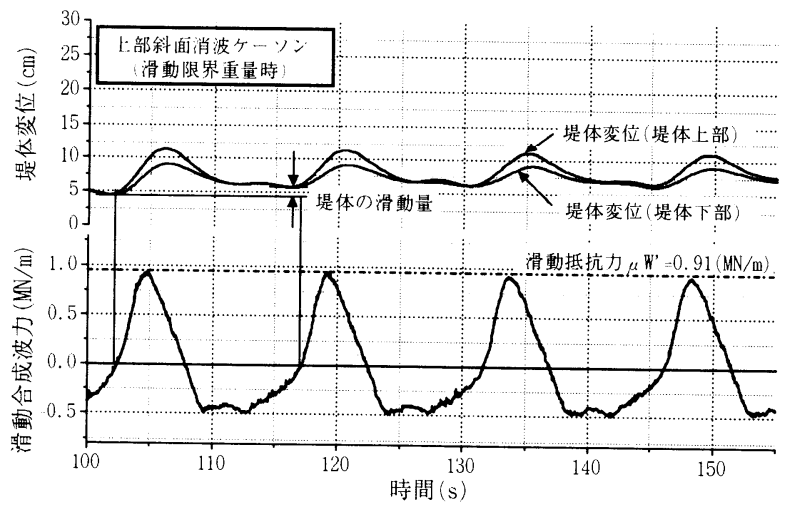

図-13 堤体変位量と滑動合成波力の時系列波形 ( $\mathrm{T}=14.5 \mathrm{~s}, \mathrm{H}=7.2 \mathrm{~m}, \mathrm{~W}^{\prime}=1.548 \mathrm{MN} / \mathrm{m}$ )

\section{(2) 越波実験}

上部斜面消波ケーソンは，斜面の効果により，耐 波安定性に優れることを確認できたが，その反面，
越波流量を増大させ，波高伝達率が増加してしまう 弱点も有している。現行の設計基準 ${ }^{6)}$ では，直立堤 の天端高hcは, 設計有義波高 $\mathrm{H}_{1 / 3}$ の0.6倍以上の適切 な高さを用いることとしている。また，上部斜面ケ ーソンの天端高に関しては, 中田ら ${ }^{7}$ が不規則波を 用いた害験を実施し，波高伝達率による天端高の検 討を行っている。その実験結果では，上部斜面ケー ソンの天端高は hc $=1.0 \mathrm{H}_{1 / 3}$ に設定すれば，直立堤で $\mathrm{hc}=0.6 \mathrm{H}_{1 / 3}$ とした場合の波高伝達率より安全側とな ることを明らかにしている，本来なら，上部斜面消 波ケーソンに関しても波高伝達率により必要天端高 を明らかにすべきであるが, 今回は, 水路の制約上, 港内側に十分な距離を確保できなかったため，越波 流量に着目して，上部斜面消波ケーソンと直立消波 ケーソンの天端高について考察を加えた。

越波害験は，波を作用させた時に堤体を越流する 水塊を, 堤体背後に設置した升で収集し，その重量 を計測することで越波流量を求めた。最初に, 既存 の模型に対して波高を変化させて越波流量を計測し た. 次に, 直立消波ケーソンでhc $=0.6 \mathrm{H}$ となる波高に 対して, 上部斜面消波ケーソンに高さの異なる 3 種類 のパラペット模型を取付けて, 直立消波ケーソンと 越波流量が等しくなる天端高を模索した。なお，今 回は基本的な越波特性を把握するのが目的であった ため，作用波は規則波としている。

図-14, 図-15に実験結果を示す。縦軸は, 単位時 間単位幅当たりの越波流量 $\mathrm{q}$, 横軸は, 相対天端高比 hc/Hとしている。プロットはすべて現地換算值であ る. 直立消波ケーソンでhc/ $\mathrm{H}=0.6$ における越波流量

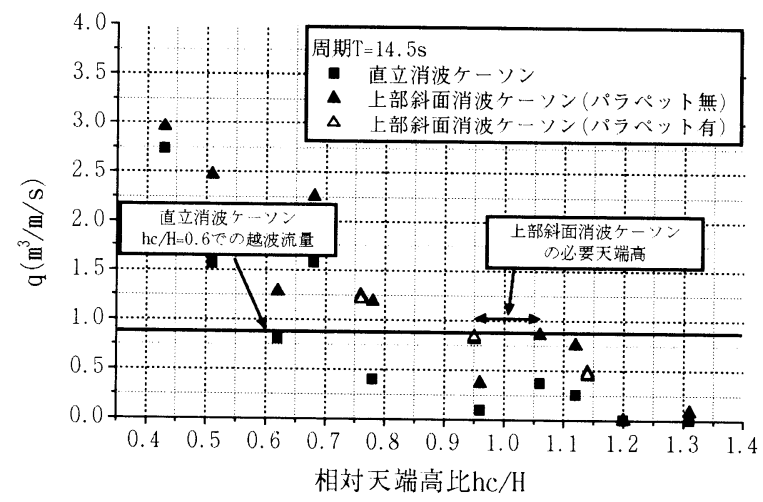

図-14 越波流量と相対天端高比の関係 $(\mathrm{T}=14.5 \mathrm{~s})$

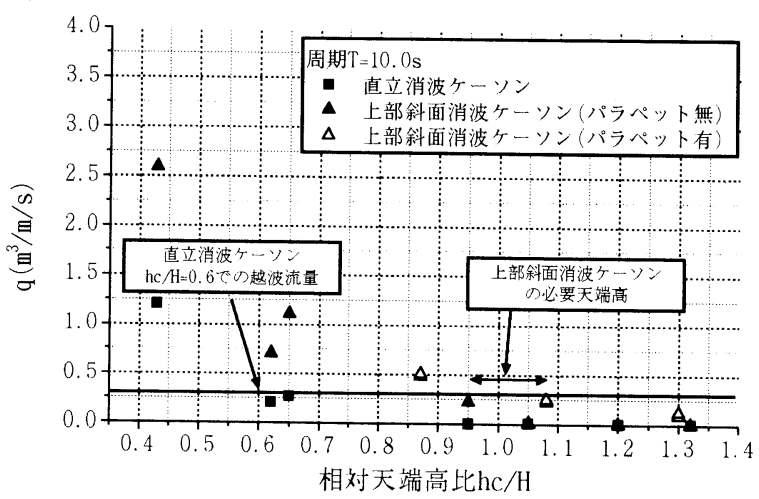

四-15 越波流量と相対天端高比の関係 $(\mathrm{T}=10.0 \mathrm{~s})$ 
と同等となる上部斜面消波ケーソンの相対天端高比 をグラフより読み取ったところ, $\mathrm{T}=10.0 \mathrm{~s}, \mathrm{~T}=14.5 \mathrm{~s}$ のいずれに対しても, 概ねhc/ $\mathrm{H}=0.9 \sim 1.1$ の範囲であ った。この結果は，直立堤と上部斜面堤の波高伝達 率が同等となる関係と同じ傾向を示している.

\section{（3）消波特性}

直立消波ケーソンと上部斜面消波ケーソンの反射 率を図-16に示す。縦軸は反射率, 横軸は波形勾配と した。 反射率の実験值は，造波機と堤体の間に設置 した波高計の測定データから合田の入・反射分離法 を用いて求めた。また，実線は直立消波ケーソンの 反射率の計算値であり，谷本ら ${ }^{8)}$ の算定法に基づい て計算した。直立消波ケーソンの実験値と計算值を 比較すると，すべてのケースに対して実験值は計算 值よりも安全側となっていた。

直立消波ケーソンと上部斜面消波ケーソンの反射 率を比較すると，すべての実験ケースで上部斜面消 波ケーソンの反射率は，直立消波ケーソンと同等， もしくは若干小さくなる傾向がみられた。このこと から，上部斜面消波ケーソンの反射率の算定に直立 消波ケーソンの算定式を代用した場合には, 安全側 の評価を得られることがわかった。

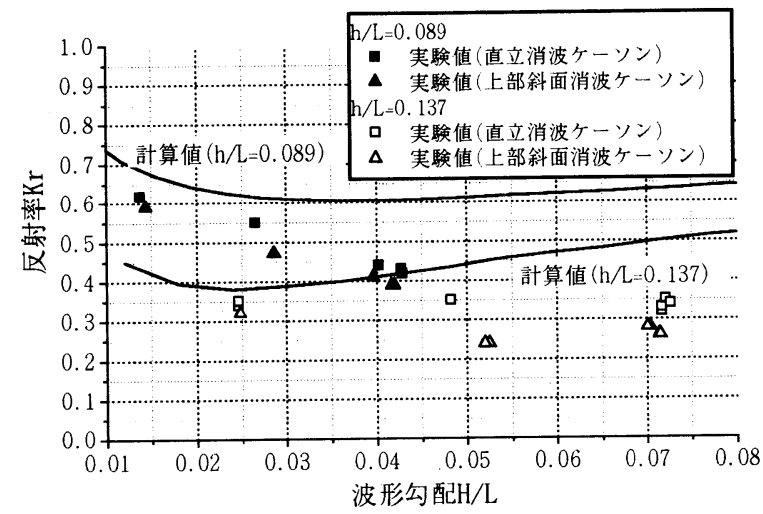

四-16 直立消波ケーソンと上部斜面消波ケーソン の反射率

\section{4.まとめ}

高波浪域向けの消波型ケーソンとして，直立消波 ケーソンと上部斜面ケーソンを組み合わせた構造で ある上部斜面消波ケーソンを考案し, 耐波安定性と 水理特性を明らかにする目的で水槽実験を実施した。 以下に，今回の実験結果より得られた結論を示す。

1)滑動実験の結果，同一の波浪条件に対して，堤体 安定上必要となる堤体重量は, 上部斜面消波ケー ソンの方が直立消波ケーソンよりも少なくてすむ
ことがわかった。したがって，上部斜面消波ケー ソンは, 建設コストの縮減に結びつく有望な構造 であるものと考えられる。

2) 滑動実験から得られた滑動限界重量と, 波力算定 式から求めたS.F. $=1.0$ となる堤体重量 (滑動限界 重量)を比較した結果, 上部斜面消波ケーソンの波 力算定式として，直立消波ケーソンの高橋らの式 に, 細山田らが提案している斜面と直立部の補正 係数を掛け合わせた算定式が適用可能であること がわかった。

3) 規則波による越波実験の結果, 直立消波ケーソン で相対天端高hc/Hを0.6としたときの越波流量と 同等の越波流量とするためには，上部斜面消波ケ ーソンの相対天端高hc/Hを0.9〜1.1とすればよい ことがわかった。

4) 上部斜面消波ケーソンの反射率は，直立消波ケー ソンと同等もしくは若干小さな值を示した。この ことから, 反射率の算定に直立消波ケーソンの反 射率の算定式を代用しても安全側となることがわ かった.

今回は, 上部斜面消波ケーソンの滑動実験結果， 及び, 越波特性, 消波特性について述べるに留まり， 波圧特性，波力特性に関しては言及していない。こ れらに関しては，今後，より詳細な検討を加えた上 で報告していく予定である.

\section{参考文献}

1) 荘司喜博 : 大型三軸圧縮試験による捨石材のせん断特性 に関する考察, 港湾技術研究所報告, 第 22 巻第 4 号, pp. 59-120, 1983

2) 谷本勝利, 原中祐人, 高橋重雄, 小松和彦, 轟正彦, 大 里睦男: 各種ケーソン式混成堤の反射・越波および波力 特性に関する模型実験，港湾技術資料，№. 246，1976

3) 高橋重雄, 下迫健一郎, 佐々木均: 直立消波ケーソンの 部材波力特性と耐波設計法, 港湾技術研究所報告, 第30 巻第4号, pp. 3-34, 1991

4) 細山田得三, 高橋重雄, 谷本勝利: 離島港湾における上 部斜面堤の適用性について, 第41回海岸工学講演会論文 集, pp. 706-710, 1994

5) 下迫健一郎, 高橋重雄: 混成防波堤の期待滑動量の計算 法, 第41回海岸工学講演会論文集, pp. 756-760, 1994

6)社団法人 日本港湾協会：港湾の施設の技術上の基準 ・ 同解説, 1999

7) 中田邦夫, 池田龍彦, 岩崎三日子, 北野雅三, 藤田隆 : 上部斜面堤の現地建設に伴う水理模型実験, 第30回海岸 工学講演会論文集, pp.313-316, 1983

8) 谷本勝利, 吉本靖俊：直立消波ケーソンの反射率に関す る理論及び実験的研究, 港湾技術研究所報告, 第 21 巻第 3号, pp. 43-77, 1982 